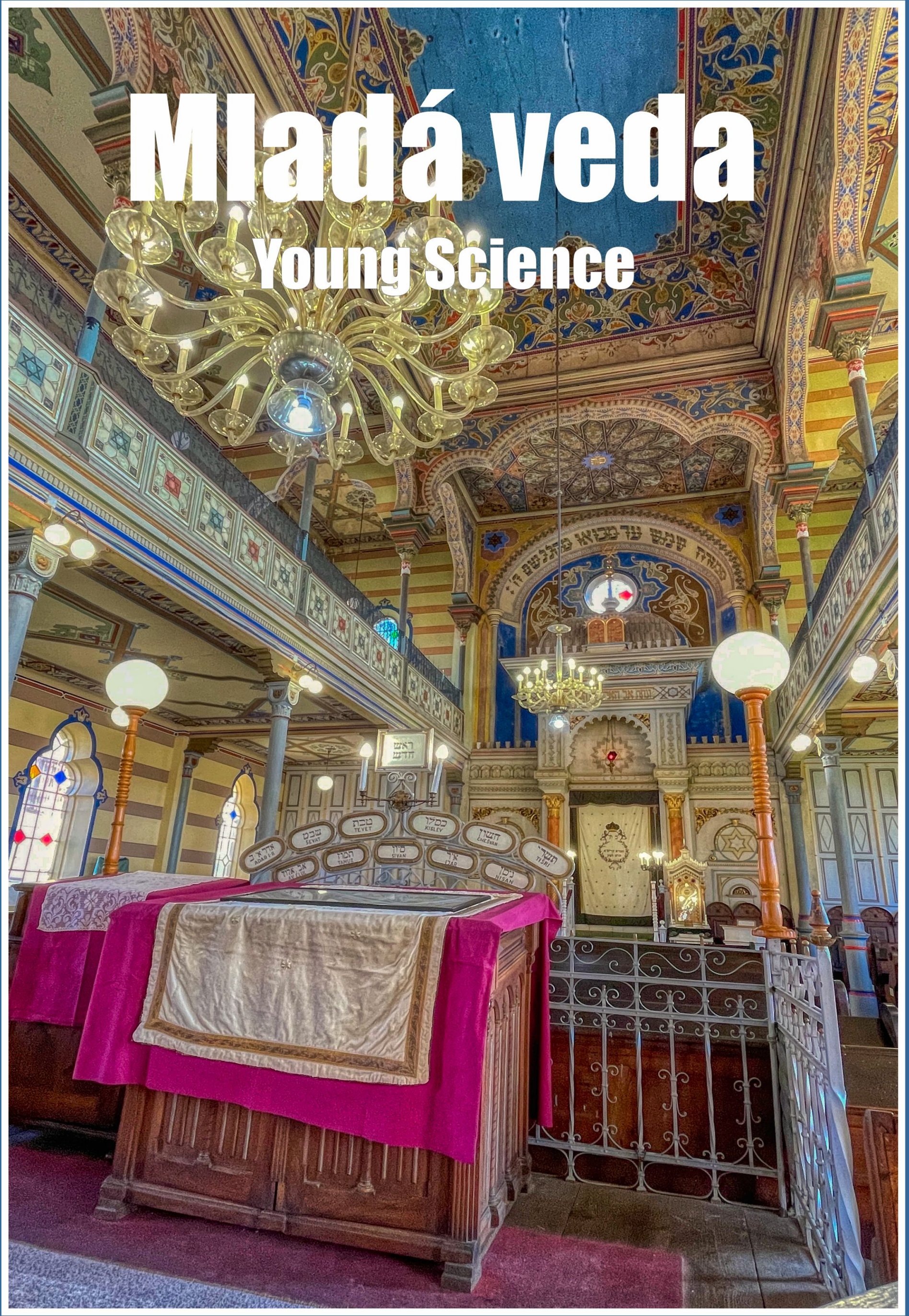




\section{Madá veda Young Science}

\section{MEDZINÁRODNÝ VEDECKÝ ČASOPIS MLADÁ VEDA / YOUNG SCIENCE}

Č́slo 3, ročník 9., vydané v októbri 2021

ISSN 1339-3189

Kontakt: info@mladaveda.sk, tel.: +421 908546 716, www.mladaveda.sk

Fotografia na obálke: Ortodoxná synagóga v Prešove. (C) Branislav A. Švorc, foto.branisko.at

\section{REDAKČNÁ RADA}

doc. Ing. Peter Adamišin, PhD. (Katedra environmentálneho manažmentu, Prešovská univerzita, Prešov)

doc. Dr. Pavel Chromý, PhD. (Katedra sociální geografie a regionálního rozvoje, Univerzita Karlova, Praha) prof. Dr. Paul Robert Magocsi (Chair of Ukrainian Studies, University of Toronto; Royal Society of Canada) Ing. Lucia Mikušová, PhD. (Ústav biochémie, výživy a ochrany zdravia, Slovenská technická univerzita, Bratislava) doc. Ing. Peter Skok, CSc. (Ekomos s. r. o., Prešov)

prof. Ing. Róbert Štefko, Ph.D. (Katedra marketingu a medzinárodného obchodu, Prešovská univerzita, Prešov) prof. PhDr. Peter Švorc, CSC., predseda (Inštitút histórie, Prešovská univerzita, Prešov)

doc. Ing. Petr Tománek, CSc. (Katedra veřejné ekonomiky, Vysoká škola báňská - Technická univerzita, Ostrava)

\section{REDAKCIA}

Mgr. Branislav A. Švorc, PhD., šéfredaktor (Vydavatel'stvo UNIVERSUM, Prešov)

PhDr. Magdaléna Keresztesová, PhD. (Fakulta stredoeurópskych štúdií UKF, Nitra)

Mgr. Martin Hajduk, PhD. (Inštitút histórie, Prešovská univerzita, Prešov)

RNDr. Richard Nikischer, Ph.D. (Ministerstvo pro místní rozvoj ČR, Praha)

PhDr. Veronika Trstianska, PhD. (Ústav stredoeurópskych jazykov a kultúr FSŠ UKF, Nitra)

Mgr. Veronika Zuskáčová (Geografický ústav, Masarykova univerzita, Brno)

VYDAVATEL

Vydavatel'stvo UNIVERSUM, spol. s r. o.

www.universum-eu.sk

Javorinská 26, 08001 Prešov

Slovenská republika

(C) Mladá veda / Young Science. Akékol'vek šírenie a rozmnožovanie textu, fotografií, údajov a iných informácií je možné len s písomným povolením redakcie. 


\title{
CURRENT SHOPPING TRENDS IN SLOVAKIA
}

\author{
AKTUÁLNE TRENDY V NAKUPOVANÍ NA SLOVENSKU
}

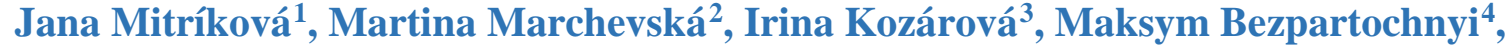 \\ Igor Britchenko ${ }^{5}$, Radostin Vazov 6
}

Všetci autori sa zo širšieho uhla pohl'adu ekonómie, manažmentu a marketingu venujú vo svojom výskume problematike súvisiacej s aktuálnymi trendami v nákupnom správaní. A to či z pohl'adu globálneho, alebo lokálneho.

In their research, all authors deal with issues related to current trends in buying and shopping behaviour from a broader perspective of economics, management or marketing, concentrating on either local or global aspects.

\begin{abstract}
Understanding the buying and shopping behaviour of current and potential consumers is essential in formulating a successful marketing strategy. It is no longer sufficient for companies to merely produce goods or provide services; companies must know who their consumers are, why they buy, when, where and at what price they buy, and what benefits they expect to gain from the purchase. Companies also need to identify how far consumers are willing to travel to make their purchases and whether the size of the sales area plays a significant role in their preferences. Retailers must also determine whether their customers prefer online shopping or want to buy and spend their leisure time in shopping centres. The paper aims at presenting the selected current trends in buying and shopping through elaborating an overview of the selected research studies and secondary data. The paper also gives an overview of contemporary trends in shopping, customer preferences with regard to

\footnotetext{
${ }^{1}$ Address: RNDr. Jana Mitríková, PhD., Department of tourism and hotel management, Faculty of Management, Prešov University, Konštantínova 16, 08001 Prešov, Slovakia

E-mail: jana.mitrikova@unipo.sk

${ }^{2}$ Address: Ing. Martina Marchevská, PhD., Department of Economics, Faculty of Management, Prešov

University, Konštantínova 16, 08001 Prešov, Slovakia

E-mail: m.marchevska@gmail.com

${ }^{3}$ Address: PhDr. Irina Kozárová, PhD., Department of Intercultural Communication, Faculty of Management, Prešov University, Konštantínova 16, 08001 Prešov, Slovakia

E-mail: irina.kozarova@unipo.sk

${ }^{4}$ Address: Prof. Dr. Maksym Bezpartochnyi, Departement of Economics and Marketing, National Aerospace University named after N. Zhukovsky „Kharkiv Aviation Institute“, Ukraine

E-mail: confer.piel@gmail.com

${ }^{5}$ Address: Prof. Dr. Igor. Britchenko, State Higher Vocational School Memorial of Professor Stanislaw Tarnowski in Tarnobrzeg, Poland

${ }^{6}$ Address: Assoc. Prof. Dr. Radostin Vazov, Vice-Rector for European Projects and Further Education, Head of "Insurance" Department, VUZF University of Finance, Business and Entrepreneurship, Bulgaria
} 
types of retail outlets, e-commerce as such, buying and shopping in the online environment and, last but not least, the changes in consumer behaviour during the COVID-19 pandemic.

Key words: consumer behaviour, e-commerce, the COVID-19 pandemic

\section{Abstrakt}

Pochopenie nákupného správania súčasných a potenciálnych spotrebitel'ov je podstatou úspešnej marketingovej orientácie na trhu. Nestačí už len vyrábat' výrobky, resp. poskytovat' služby, je potrebné poznat', kto je spotrebitel', prečo nakupuje, kedy a kde nakupuje, za akú cenu a aký úžitok od nákupu očakáva. Akú vzdialenost' je ochotný prejst' za nákupmi, či hrá v tejto preferencii podstatnú úlohu predajná plocha predajne, alebo vzdialenost'. Či preferuje online prostredie, alebo chce okrem nákupov (hlavne) v nákupných centrách trávit’ aj svoj vol'ný čas. Ciel'om nášho príspevku bolo zhodnotit' vybrané súčasné trendy v nakupovaní prostredníctvom spracovania prehl'adu vybraných výskumov a sekundárnych dát. V príspevku sa stručne venujeme prehl'adu súčasných trendov v nakupovaní, preferenciám spotrebitel'ov podl'a typu predajní, elektronickému obchodu ako takému, nakupovaniu v online prostredí a v neposlednom rade aj zmenám $\mathrm{v}$ spotrebitel'skom správaní počas trvania pandémie COVID-19.

Kl'účové slová: nákupné správanie, e-commerce, pandémia COVID-19

\section{Introcuction}

The study of consumer behaviour is the study of the behaviour of individuals, groups or organizations and of all of the activities related to the purchase, use and sale of goods and services including the emotional, mental and behavioural reactions of consumers. The field emerged in the 1940s and 1950s as a crucial subdiscipline in the study of marketing and is essentially an interdisciplinary social science that combines elements from psychology, sociology, social anthropology, ethnography, marketing and economics, with a particular focus on behavioural economics to examine how emotions, attitudes and preferences can influence consumer behaviour. Formal consumer behaviour studies examine all possible characteristics of individual consumers, such as demographics and lifestyles and behavioural variables such as usage rates, use opportunities, brand loyalty and advocacy, willingness to make recommendations in an effort to understand people's needs and consumption. The study of consumer behaviour also examines the effects of factors such as family, friends, sports, reference groups and society in general on consumers' choices (Kahle and Close 2011).

Gburová and Bačík (2013) define the term consumer behaviour as "the behaviour by which consumers express themselves when evaluating, searching for, buying and using the services and products from which they expect to satisfy their needs”. Consumer behaviour examines the actions of both individuals and households in buying goods and services for personal consumption, thereby forming a collective consumer market (Gburová and Bačík 2013).

According to Solomon (2006 as cited by Štefko et al. 2012, 73), “consumer behaviour is the process by which individuals or groups select, purchase, use and dispose of goods, services, ideas or experiences to fulfil their needs and desires”. 
It is possible to suggest that an image of the individual and their social or cultural differences can be identified wherever the processes of consumption and purchasing take place. When buying goods or services, consumers do not always behave rationally and it is not generally possible to identify fixed patterns in consumer behaviour. A wide variety of subjective factors such as the appearance of a shop, the manner of the staff or the range of goods displayed on the shelves can affect buyer behaviour. On the other hand, objective variables carry a greater weight in the consumer decision-making process, primarily those of price and accessibility. Consumer behaviour is often described as a mysterious process because it is often unpredictable and can sometimes appear illogical. Also important in this respect are the seemingly irrational seasonal fluctuations in sales over the course of the year. Advertising in particular has a significant influence on the consumer behaviour of customers and can be an immensely powerful tool for making an impression on consumers (Križan and Lauko 2014). Although consumer behaviour can be influenced and changed through advertising, this remains a somewhat "fuzzy" phenomenon which cannot be simplified into a series of graphs and tables. (Križan, Barlík and Bilková 2016). In order to succeed in retail sales, it is necessary to develop a detailed knowledge of consumer behaviour, a process which has changed significantly in line with the developments in the retail industry and also in society as a whole. These changes have generally been the result of three distinct factors: demand, supply and the availability of resources, all of which are strongly influenced by the economic conditions of households. Consumer behaviour is manifested through a specific process in which consumers evaluate and compare the available alternatives and decide for some of these over others (Trembošová, Dubcová and Civán̆ 2016 as cited by Mitríková 2017). Consumer shopping is not limited by location, and the choice of where to shop is influenced by many factors. If consumers are not satisfied with the goods or purchase in their locality, they can choose to make purchases someplace else (out-shopping, out-of-town shopping) in an attempt to satisfy their requirements. Cross-border shopping can be considered as a special subcategory of this type of purchases (Sullivan and Kang 1997; Križan and Zeman et al. 2017). Most current studies evaluating consumer behaviour focus on the behaviour of consumers in shopping centres. These locations represent a new form of sales that displaces traditional forms of shopping and reshapes the shopping habits of new generations of consumers. Shopping centres are not only a locus in which purchases are made but they have also gradually developed into sites for other services, cultural activities or other events in order to attract as many potential customers as possible. Although consumers under the age of 35 form the main group of visitors to shopping centres (Kunc, Tonev, Szczyrba and Frantál 2012; Spilková 2012), these new formats are also the bearers of changes for other generations of consumers, including the elderly. Križan and Lauko (2014) term this type of consumer behaviour as leisure shopping, with shopping increasingly seen as a way of unwinding and relaxing. For many families, shopping centres are popular places in which to spend their weekends, and it is possible to talk about so-called "fun shopping" or "experience shopping" in this context, an activity which directly emphasises shopping centres' role as a space for the spending of free time, not just shopping (Spilková 2012). Shopping centres also function as a social space in which people can meet up and spend time together. The growth of such behaviour leads to the construction of new shopping centres, which over time change not only 
our surroundings but also our habits, leisure activities and our lives in general (Trembošová 2009). Therefore, in this context, shopping centres can be considered as "tourist destinations"; by offering attractions and services, they create a recreational potential for the development of modern urban tourism (Spilková 2012, Mitríková, Šenková and Antoliková 2015). According to Kita $(2005,75)$, consumer behaviour represents "obvious and observable acts, such as purchase and consumption [...], mental and social processes that take place: 1 . before purchase, 2. during purchase, 3. after purchase”.

\section{Current shopping trends in Slovakia}

At the end of January 2018, research into the shopping behaviour of Slovak consumers was carried out by the Institute of Sociology of the Slovak Academy of Sciences in the form of personal surveys. The sample consisted of 1012 respondents representing the population of the Slovak Republic over the age of 18 in terms of gender, age, education, nationality, municipal category and region. The field data collection was carried out by the FOCUS agency. According to the survey, Slovak consumers primarily shop in large retail stores such as hypermarkets and shopping centres (42\%) and supermarkets (34.2\%); in total, more than three quarters (76.2\%) of all consumers regularly shopping in these types of retail units. In this context, it should be noted that the history of Western companies has shown that large department stores and shopping malls have had a major influence on the emergence and expansion of consumer societies and consumer culture. These types of retail outlets offer sufficient possibilities of choice and range of goods, which is understood as a feature of consumer freedom typical of consumer culture. The number of respondents to the survey who reported shopping in smaller self-service shops is significantly smaller, with only around every sixth respondent shopping in them (14.3\%). Even less popular are smaller over-thecounter shops, in which only $3.8 \%$ of consumers shop. Online stores $(0.5 \%)$ and marketplaces $(0.2 \%)$ had a completely marginal position in terms of purchasing food, drugstore articles and other everyday consumer goods in 2018. Approximately 5\% of respondents do not buy in person, with others shopping for them. Hypermarkets and shopping centres tended to appeal to a younger clientele, with $64 \%$ of the $25-34$ age group and $51 \%$ of the $35-44$ age group reporting shopping in these locations, with the first age group in particular representing a generation of who have already been born into a society in which large shopping centres are a part of everyday life. This generational aspect is also important because it is the younger generation that is most often the carrier of social change, and it is therefore predictable that it was this generation that was the first to adopt an accelerated consumer culture. The majority of respondents with a university degree (58.9\%) and respondents living in cities with more than 100,000 inhabitants (54\%) and in the Bratislava Region (65\%) also displayed a preference for shopping in large stores which can be expected to offer a wider range of goods. At the same time, this growing preference for shopping in large stores in Slovak society may indicate why the representatives of consumer cooperatives and small traders were among the first to call for a ban on Sunday sales at the beginning of the millennium (Búzik and Zeman 2020).

As for marketers, the geographical perspective is also highly important for psychologists or sociologists researching consumer shopping behaviour. Within the 
geography of Slovak retail and consumption, attention is often focused on consumer shopping behaviour in terms of location, either in the analysis of the urban environment (e.g. Križan et al. 2015, Mitríková 2017, Trembošová et al. 2016) or, more rarely, of the rural environment (Bilková et al. 2017). One topic connected to this field of study is that of dual food quality, with politicians beginning to pay considerable attention in an effort to ensure that products sold in the European Union's retail market are standardised in terms of quality. In this context, the topic of cross-border shopping can be considered relevant, but this issue has not been widely discussed in Slovak geography to date (Civáň and Krogmann 2012), although the phenomenon of the more widespread development of cross-border shopping by Slovak consumers can be traced back more than a quarter of a century (Williams et al. 2001). At the same time, it can be stated that the problem of cross-border shopping of Slovak consumers has not gone unnoticed by experts from other scientific disciplines such as Baláž 2006, Baláž and Williams 2005, Williams and Baláž 2002, Williams et al. 2001). Studies seem to suggest that consumers from Slovakia spend a third more on purchases in Austria than on purchases in Slovakia, indicating that Slovak consumers have different shopping behaviour or preferences in the two countries. This to some extent refutes the findings of Kovács (2013) who analysed cross-border shopping in the Slovak-Hungarian border area but generally confirms the specific shopping behaviour of Slovak consumers in spending more money on purchases abroad than was the case for consumers from the other side of the border, thereby creating a negative balance of cross-border purchases for Slovak retail (cf. Civáň and Krogman 2012, Kovács 2013, Sikos and Kovács 2008, Tömöri 2010). A survey carried out by Jarossova (2015) shows that few consumers buy food from local producers, possibly due to relatively low share of Slovak products in some retail chains whose shelves are dominated by food from Poland, the Czech Republic, Hungary, Spain and other countries. Slovak consumers are more likely to buy food in retail chains (supermarkets or hypermarkets), and less likely to purchase from local producers or smaller private entrepreneurs.

\section{E-commerce and consumer behaviour in the online environment}

Retail shops have a long tradition all around the world, with specific traditions and customs developing since the earliest days of retail trade when the exchange business was still in a primitive form. Over time, the retail store has undergone continual improvement, and nowadays, retail stores are found all over the world. One major development, however, has been the emergence of online shopping which allows us to purchase goods from the comfort of our homes, saving time and offering the delivery of a wide range of assortment directly to our front door. Internet shopping originally focussed on the sale of goods such as clothing, books, electronics, but it has also recently expanded into food retail. As much research has confirmed, online social networks also have a significant impact on consumers' purchase decisions (Britchento 2001; Hasan 2019).

The concept of electronic commerce (e-commerce) is often identified with the concept of electronic business (e-business), but this is not entirely correct from a factual point of view.

- E-commerce usually refers to the purchase and sale of goods and services through the use of information technologies. This term often refers only to the very act of purchasing goods by customers, but it involves much more than the mere execution of 
transactions between companies and consumers. We define e-commerce as all monetary and non-monetary interactions performed between companies and all other parties involved in the buying process. According to this definition, transactions can thus be non-financial in nature and the provision of information to customers is also included in the concept (Hasan and Uhrín 2020).

- Electronic business is a complex interconnection of a company's business activities with customers, suppliers, partners and employees through information technologies. This means the use of the Internet for the purpose of ensuring all aspects of a company's business activities (Chaffey 2007, 8 as cited by Hasan and Uhrín 2020). Electronic business is the innovative use of Internet technologies to increase the efficiency of business processes, minimizing costs and maximizing profits. The Internet allows companies to communicate with partners, sellers and customers in a simpler way (Hasan and Uhrín 2020).

According to Bystrická (2013), e-commerce is a subset of e-business. Electronic commerce can generally be spoken of when any information and communication technologies are used in order to carry out mutually beneficial transactions between a seller and a buyer (Bystrická 2013). The implementation of an information system into business processes or the creation of an information infrastructure does not mean that it is exclusively a question of electronic commerce. A company can only be included in this category when it communicates with customers mainly through information and communication technologies, which can also be used by the implemented information system (Laudon and Traver 2016, Horváth and Bačík 2020).

In a simplified way, e-commerce is defined as the purchase, sale or exchange of business information, money, goods or services through the Internet or through fixed or mobile networks. E-commerce can be carried out in two ways (Kristová 2006, 90 as cited by Hasan and Uhrín 2020):

- Indirect e-commerce which is understood as the use of information technologies to order goods and services that cannot be distributed to consumers in electronic form. This can include, for example, various consumer goods or travel agency products.

- Direct e-commerce in which all steps of the purchasing process are performed through the Internet. A consumer can order selected goods which will be delivered to them in electronic form after payment. There will be no physical contact between a seller and a customer. Direct e-commerce is typical for purchases of products such as, for example, software, music or e-books which can be provided entirely in electronic form.

Companies invest in information technologies and e-commerce in order to increase the efficiency of their operations and improve their services to customers. It is typical to prefix the names of activities which takes place through the Internet with the letter "e" (as electronic), coining phrases such as e-business (electronic business), a term which is usually understood as a broader concept than e-commerce (Blažková 2005 as cited by Kakalejčík 2015). Electronic commerce (or e-commerce) is a business that is implemented in an online environment, with the Internet serving as the single platform that connects sellers and buyers (Tan 2013 as cited by Kakalejčík 2015). According to Ullman (2013), e-commerce represents 
the entire range of possible commercial transactions which can be performed online, and also includes any website that is intended to generate revenue. Qin (2010) defines e-commerce as social and economic activities conducted between participants using computer equipment and the Internet, but the rapid spread of mobile devices and their use in commercial purposes has rendered this description obsolete in its original wording. Minculete (2013) states that ecommerce and e-business are losing the letter " $\mathrm{e}$ " because the use of e-commerce technologies is increasing in companies and these technologies are becoming a common part of marketing activities. The main tool used in e-commerce is an e-shop, a retail outlet which operates exclusively online (Beynon-Davies 2012 as cited by Kakalejčík 2015).

Online shopping has gone hand in hand with the rise of the Internet. In the early 1990s, companies began to use the Internet for promotional purposes and for making contact with customers, primarily in terms of conveying product presentations, company information, contacts and manuals. The first online shops as we know them today began to emerge in 1994 as companies slowly began to realize the potential of the Internet to connect with millions of people around the world. Encryption technologies which ensured the transmission of credit card data was an essential component of the development of electronic shopping. Since then, server technologies have evolved, enabling the creation of e-shops which can offer several thousand products. The greater the range of products offered on the Internet, the higher the number of visitors to Internet portals (Tomek and Vávrová, 2011).

Williams et al. (2006) note that while consumers continue to shop in brick-and-mortar stores, they appreciate the convenience of shopping online because they do not have to visit large stores in person. They add that shopping online saves the time and energy of consumers when shopping for the commodities in which they are interested. In the case of online shopping, purchases can be made simply and securely from the comfort of home. Online shopping is an extremely useful means of satisfying the needs and desires of consumers, and a study by Brown et al. (2003 as cited by Oleárová 2020) confirms that the Internet allows consumers to make more sensible decisions in a way that is not possible in the traditional shopping experience.

The world is "currently experiencing a digital boom that is also manifesting itself in the field of commerce, where the shift of business to the Internet platform is evident. E-commerce [... includes] not only online shopping, but also several other processes such as creating appropriate promotions, buying and selling various goods, but also [carrying out] public relations" (Hasan 2019). E-commerce offers distinct advantages to vendors, allowing them to pursue business opportunities without requiring investment into a bricks-and-mortar shop, but it also benefits to customers by allowing direct contact between the seller and the buyer through electronic systems without the need for personal communication, and also ensures lower prices, more efficient shopping experience and access to a wider range of products (Hasan 2019).

Methods of payment are, of course, a crucial issue in e-commerce. As online shopping has become more popular, a large number of possible means of payment have been developed, including the digital use of credit cards and debit cards, smart cards, e-wallets or online bank transfers, all of which are becming more widely used for e-commerce transactions. Online payments or e-payments are initiated, processed and received electronically through the 


\section{Internet (Kunešová and Eger 2017).}

Electronic commerce has brought about a revolution in business practices (Ohidujjaman et al. 2013). Khan and Mahapatra (2009) argue that the agricultural and industrial revolutions of the eighteenth and nineteenth centuries have been followed by a third revolutionary economic wave with the advent of the Internet, and that that information technologies can play an important role in the development and improvement of services across all business sectors. The e-commerce SWOT analysis performed by Awais and Samin (2012) highlights the ubiquity, low operating costs, improved customer interaction and time savings as unique strengths of e-commerce. The ubiquitous nature of the Internet has allowed e-commerce to overcome geographical boundaries and penetrate into different markets, moving on to generate demand for suburban and rural areas after successfully realizing its potential in metropolitan cities. In light of the growing number of websites offering similar goods and services, an increasing importance is being attached to internet marketing, which will not only promote e-commerce but also emerge as an important tool in promoting bricks-and-mortar shops (Gangeshwer 2013).

By 2019, 3.5 million Slovaks were regularly online, with people between the ages of 25 and 44 with a secondary education the most common users. Slovak men typically spend more time online than women by an average of one hour and sixteen minutes per day and also accessed $18 \%$ more web pages than women. Slovak customers spent $€ 1.36$ billion on domestic online stores in 2019, and the interannual growth of sales in e-shops increased by 20\% in 2020. The Christmas season, which opens in mid-November with Black Friday sales, is typically the most intensive shopping season in traditional retail, but e-commerce reaches the highest numbers in the second week of December, when buyers usually have the last chance to make purchases with guaranteed delivery by Christmas Day (Heureka 2020). During this period, the traffic of Slovak websites was mostly generated directly from links from social networks, either organic or promoted posts on Facebook and Instagram (IAB Slovakia 2019).

Based on the survey in which 962 respondents belonging to Generation $\mathrm{Y}$ took part, Horváth and Bačík (2020) suggest that representatives of Generation Y buy goods and services online several times over the course of the year. Based on the average or median values, the items most frequently bought online were clothes and jewellery, services such as cinema tickets, holidays or tickets for cultural events, travel tickets or cosmetics and perfumes, while the least frequently purchased products included lottery tickets, automobile products, music, PCs and insurance. The lowest variability, i.e. the smallest difference within the specific answers, was recorded for automobile products, lottery and betting items, with the purchase of travel tickets, food and groceries, cosmetics and perfumes showing the highest variability.

\section{Social networks and e-commerce}

New trends in marketing communication which have emerged in recent years are directly connected with the Internet. The Internet age has given rise to new types of retailers who operate their business mainly online through websites and e-shops, without the need for the traditional presence in the market in the form of brick-and-mortar stores. More traditional 
retailers have become aware of this competitive struggle, and thus many brick-and-mortar companies have expanded their activities to include e-marketing, being termed hybrid companies within their field (Kotler and Keller 2007). Social networks and social media have now emerged as a significant phenomenon because they represent the possibility of mutual communication between retailer and customer and also between customers. Although they are not a place of purchase, communities on these networks interact with and influence each other, and their importance can be expected to grow further in the future (Vysekalová et al. 2012).

Marketers need to be where their customers and potential customers are, and in the modern day consumers are more likely to be found on the Internet and social networking sites. Sites like Facebook have hundreds of millions of active users from all continents and they spend a collective total of 2.6 billion minutes on Facebook every day. Social networks are emerging as a powerful and sophisticated new type of marketing channel which allows marketing approaches which are more precise, personal and social. Social networks give marketers new campaigning capabilities through exploiting users' profile information, engaging community members by drawing on social capital within groups of friends, and systematically refining marketing with personal recommendations across existing customer bases (Shih 2010). Social networks have become a phenomenon of our age to which many people are now addicted; an integral part of our lives, a topic that affects us every single day. A social network can be understood as a set of relationships at the social level which also operate between the individual elements, or users, of the network. Their potential marketing use is vast because they gather together a huge share of consumers or potential customers, which on the one hand offers marketers the possibility of direct marketing or brand building, but on the other hand, provides them with a large amount of information about their clientele (Scott 2010).

However, many retailers have struggled to adapt to the new environment of social media. One serious mistake that retailers make is to use social media to talk about what they consider is important to them rather than talking about what is important to the customer. Retailers should provide content that is relevant to their customers and always remain aware of the necessity of customer feedback which contributes to the elimination of deficiencies on the side of the retailer (Hudson 2019 as cited by Nastišin 2020).

\section{Changes in consumer behaviour during the corona crisis}

Consumer behaviour is not fixed and ongoing, and it can undergo processes of transformation. These changes can be influenced by internal factors, such as age or income, or by external factors, such as an economic crisis or the opening of a new store. The COVID-19 pandemic has been one of the most significant external factors shaping consumer behaviour in recent years. The the various consequences of the pandemic have changed the course of our society, with the familiar world to which we have become accustomed to being changed in virtually every respect, day by day and wave by wave. Retail outlets with the exception of groceries were closed, and the majority of services could only operate to a restricted degree, so it is unsurprising that this has had a significant impact on consumer behaviour (Križan et al. 2020).

The coronavirus pandemic has seriously disrupted and changed business conditions and the 
structure and volume of services around the world and e-commerce is no exception to this, although at first glance it might seem that it has been and will be less severely affected than some other areas. Many businesses in China, Europe or the USA have come to a complete halt, and while e-commerce continues to operate, its operation has been affected by the impact of the pandemic in other ways (Britchenko 2020; Sikandar 2020).

While uncertainty surrounding the continuing course of COVID-19 persists around the world, its impact is felt differently in each country. As a result, there are significant differences in how consumers have responded to the crisis and adapted to the "new normal" (McKinsey 2020).

According to Valassis (2020), a marketing company which conducted a survey with a sample of 1,000 adult consumers in the USA on 16 March 2020, half of the respondents stated that they had changed their behaviour concerning online shopping during the COVID-19 pandemic. The survey showed that $42 \%$ of consumers shopped more through the Internet, with only $8 \%$ of consumers shopping less online than before the pandemic. Among other things, the survey revealed that the pandemic has forced some consumers to increase their use of delivery services. 14\% of respondents answered that they had used food ordering and home delivery for the first time due to the pandemic, and $13 \%$ of respondents answered that they had increased the frequency of their online food purchases. Almost a third of respondents had not yet used the alternative of food delivery to their home but were considering doing so. The company also examined the situation of delivering prepared meals from restaurants. According to the survey, $10 \%$ of respondents had used this service for the first time due to the pandemic and $14 \%$ of respondents ordered food more often through the Internet than before. As many as $27 \%$ of respondents had not used food delivery service but were considering doing so.

According to Taylor (2020) "while the surge in e-Commerce ordering drives more immediate revenue for retailers, it puts added pressure on the supply chain. Amazon has already had to ban the acceptance of non-essential items from retailers in its U.S. and UK headquarters to prioritize high-demand products and medical supplies, and there have been reports that some deliveries of Amazon Prime have been delayed by up to a month. Given that most other retailers don't have the robust supply chain and fulfillment networks that Amazon does, it's likely that many are feeling stretched thin with delays of their own.”

A report by Listrak (2020) even recorded a $40 \%$ jump in e-commerce sales during the pandemic period. According to MediaRadar (2020 as cited by Listrak 2020), e-commerce websites in the United States have responded to this fact by doubling their advertising spending in less than a month, from \$ 4.8 million in the week of February 17 to \$ 9.6 million in the week of March 9.

According to a March survey by the retail analysts First Insight (2020 as cited by Oleárová 2020), most US consumers (66\%) fear the spread of the disease and more than two-fifths (44\%) of shoppers say these concerns have already influenced their purchasing decisions. Almost one third (30\%) said they already shop less regularly in brick-and-mortar stores, and one fifth (21\%) said they prefer e-commerce when shopping. Consumers are also seeking out modern retail solutions. In their increasing dependence on online shopping, they also use the "buy online, pick-up in store" method to mitigate the risks associated with in-person 
shopping. More than a quarter (29\%) of respondents to the First Insight survey said that they used online shopping services to deliver products to their homes, while up to $18 \%$ of consumers said they preferred curbside pickup. This survey also revealed other interesting findings about how the pandemic situation had changed consumer behaviour. Nearly half (49\%) of all respondents expressed concerns about receiving clothes or other products that had been produced in affected areas or from the initial source of the outbreak, China. If consumers are changing their online shopping behaviour due to the pandemic, the current period can be expected to make a significant contribution to the growth and development of ecommerce. Today more than ever, businesses are realizing the importance of a strong digital presence, and e-commerce habits tend to develop during periods of intense activity. The results published by various companies and research agencies and presented above have proactively mapped the current situation. However, the situation continues to change every week and therefore it will be interesting to monitor the global impact of the COVID-19 pandemic on e-commerce over time, or whether the intensity of the impact will be similar in individual countries (Oleárová 2020).

The EY Future Consumer Index (Rogers 2020 as cited by Štrach 2020) identifies four different customer segments in their examination of the impact of the pandemic on consumer spending. The "hibernate and spend" segment is deeply concerned about the impact of the pandemic but essentially maintains their pre-Covid shopping habits and continues to value brands. The "cut deep" category of consumers are mostly older than 45 and are thus in danger of losing their jobs. A great majority of them shops less frequently and only purchases essential supplies with little regard for brands. While the segment labelled "save and stockpile” has cut their spending on leisure and clothing, these stockpiling "hamsters" are concerned about their families and the long-term effects of the pandemic and go on grocery shopping sprees in order to ensure that they have enough essentials for the year to come. The "stay calm, carry on” segment tries to continue in their pre-Covid consumer behaviour and lead their lives unchanged. If "stay calm, carry on" consumers are worried about anything, then it is the stockpiling and unusual behaviours of others (Štrach 2020).

A more recent study by the same company entitled "EY Future Consumer Index: Five consumer segments will emerge beyond COVID-19" (Rogers examines five new customer segments which organizations will need to engage beyond COVID-19. Each segment reflects different ways in which people expect to live their lives, how they make decisions and what they really care about. Rogers (2020 as cited by Štrach 2020) state that "two of these segments highlight the way that many consumers will focus on living within their means and looking after their health, and the health of their families ("affordability first" and "health first"). Another two point to the way some consumers will make their environmental and social concerns central to their lives ("planet first" and "society first"). And the final one identifies the consumers who will focus on living in the moment and getting the most from every experience ("Experience first”)". "Affordability first” is the most numerous of the future segments; it represents $30 \%$ of consumers whose priority is to live within their means, who avoid buying things they do not really need and when they have to buy anything and who search for the best deals. "Health first" represents the second biggest segment, accounting for $26 \%$ of consumers worldwide. "Planet first" consists of $17 \%$ of consumers who are fully 
conscious of the impact of their consumption decisions on the world around them. "Society first" refers to $16 \%$ of consumers who believe that everyone should work together for the common good and who focus their attention on the social impact of what they buy and consume, buying from organizations that are honest and transparent about their activities (Rogers 2020 as cited by Štrach 2020).

McKinsey has also identified five trends in consumer behaviour: digital and online shopping; the evaporation of loyalty as many consumers switch brands at an unprecedented rate; a rise in health and safety concerns; a renewed interest in value for money; and the emergence of the homebody economy (McKinsey 2020).

Jucha and Corejová (2020) examined secondary sources available on the internet and reported an increase in the number of customers shopping online or changes in the structure of sales and thus changes in demand in the e-commerce sector during the course of the Covid pandemic in some countries, especially in the USA, Italy, Spain and Germany. Among EU countries, their research focused on Italy and Spain because these were the countries most affected by the coronavirus pandemic in the EU in 2020, while Germany drew their attention due to its position as one of the largest e-commerce markets in the world.

The results of their research show that US food consumers started to buy meat and seafood online, with these products seeing an increase in online sales of up to $173 \%$ in comparison to the previous year. Other food products, such as dairy, cheese and eggs, saw smaller increases but their online sales still rose by 36\%. This suggests that customers buy food with the longest shelf life online, meaning that they are less likely to buy regular food products with shorter shelvlives less often online. The increased online purchase of food was probably due to the fact that US inhabitants were less likely to visit brick-and-mortar shops during the coronavirus pandemic. Among other things, there was a significant increase in the purchase of air cleaners, with an increase of up to $74 \%$. This is probably related to growing consumer concern about health issues in the shadow of the pandemic (Macdonald 2020 as cited by Jucha and Čorejová 2020).

In the case of both Italy and Spain, a significant change was noted in online sales of sports products. This had ranked fifth in the list of top product categories purchased through ecommerce in 2019, lagging behind clothes, electronics, books, cosmetics and furniture. However, sports goods saw the largest increase in online sales in both countries during the coronavirus pandemic in 2020, a 236\% increase in Italy and a 191\% increase in Spain. Both Spaniards and Italians are known for their active lifestyles and it seems likely that not even the pandemic could dampen their enthusiasm in this regard (Hoeijmans 2020, Jucha and Črejová 2020).

The large increase in sales of toys and board games in Germany is an interesting trend which is probably the result of quarantine measures and changes in the ways in which families spend their leisure time. In comparison, toys were among the product categories least ordered through e-commerce in 2019 (E-commerce in Europe 2019).

Križan et al. (2020) compared surveys of panic shopping in food retail conducted by Hall et al. (2020) and Ben Hassen et al. (2020) and Jeżewska-Zychowicz et al. (2020), observing some countries did not record panic shopping behaviour or stockpiling of food or drugstore goods. In Slovakia, however, panic buying was a marked feature of the early stages of the 
Covid pandemic. According to Karel Týra, the CEO of Nielsen Slovakia in the Czech and Slovak Republics, the first most significant turnaround in consumer behaviour occurred in Slovakia "in the $11^{\text {th }}$ week of 2020 (i.e. from 9 to 15 March 2020), when sales of food and drugstore goods jumped upwards, by more than $30 \%$ compared to the previous year. That week was exceptional with its dramatic leap and record turnovers. For retailers, it was the second most successful week of the year after the pre-Christmas third week of December. Even sales in the 2019 or 2018 pre-Easter week, which tend to be the second strongest period without exception, did not reach the turnover of the $11^{\text {th }}$ week of 2020. The market of Slovak hypermarkets and supermarkets recorded a $28 \%$ increase in turnover in that period. However, a much more dynamic pace of growth was observed in the networks of drugstores, which had managed to maintain a faster growth rate for a long period of time. During the pandemic, this overall trend of increasing in their importance was confirmed and in the $11^{\text {th }}$ week of that year they managed to increase their turnover up to twice as fast as was the turnover of food chains, i.e. by 57\% compared to last year” (FMCG \& RETAIL 2020).

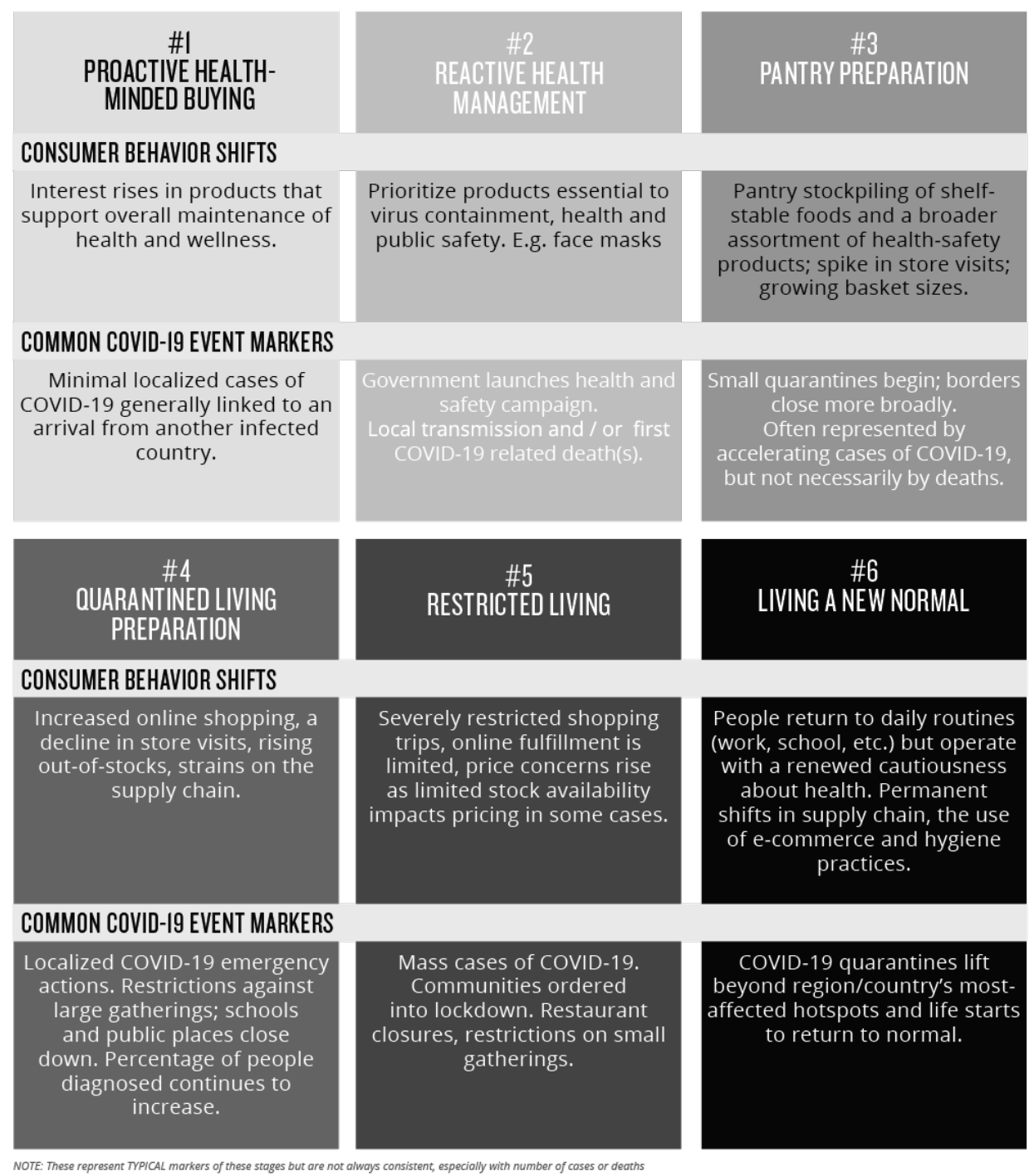

Figure 1 - Nielsen six consumer behaviour thresholds of COVID-19 concern Source: CPG, FMCG and RETAIL, 2020 
If we compare sales for the three weeks from the beginning of the shopping spree, i.e. from the 9th to 11th week of 2020, the fastest-growing categories include hand disinfectants, the sales of which increased by almost 560\%, laundry disinfectants with a sales increase of more than $530 \%$, and wet wipes with a sales increase of $443 \%$ compared to the same three-week period in 2019. The turnover of household disinfectants increased by 335\%, liquid soaps by $255 \%$ and standard toilet soaps by $175 \%$. Slovaks also bought baking ingredients in much higher quantities (an increase in turnover of 233\%) and empty shelves of toilet paper were a regular sight as these products rapidly sold out. Turnover of toilet paper doubled in this period, with toilet paper standing out as one of the best-selling goods during those three weeks (FMCG \& RETAIL 2020).

Nielsen defined six key threshold levels of consumer behaviour that are directly related to the new COVID-19 pandemic concerns - from the first stages, when the first information about Covid-19 trickled out leading to a stockpiling of medicines, to the later stages of the return to the normal pre-pandemic life. Their findings showed that Slovakia was in the fourth stage by March 2019, that in which consumers had already made their initial purchases of supplies and had started to shop online to a greater extent (FMCG \& RETAIL 2020).

In the spring of 2020 people filled their shopping baskets with long-life food. Sales of rice increased by $220 \%$, pulses by $186 \%$, flour by $172 \%$, granulated sugar by $158 \%$ and pasta by $150 \%$. The entire group of non-alcoholic beverages, which recorded an overall year-on-year growth by $16 \%$ during the abovementioned three-week period, were also the focus of consumers. However, Slovaks were reluctant to supply alcoholic beverages, the turnover of which increased by only a moderate $5 \%$, a growth rate much slower than that of their Czech neighbours, whose spending on alcohol increased by $14 \%$ in comparison with the previous year. Slovaks also spent a fifth more on fresh food and around a tenth more on sweets. They also stockpiled for their pets, spending $17 \%$ more on dog and cat food than the previous year. Although online food sales have played a less important role in Slovakia, consumers are more interested in the possibility of e-commerce and also have more opportunities to buy through the e-shops than in the past. Even those who were not enthusiastic about technology before the pandemic are now less likely perceive barriers when trying to use new online shopping possibilities (FMCG and RETAIL 2020). In general, after an initial sharp increase in expenditure in retail (as frontloading or panic buying took hold), there was a general decrease in expenditure in retail trade and services (Baker et al. 2020 as cited by Križan et al. 2020). Grashuis et al. (2020 as cited by Križan 2020) concluded that the COVID-19 pandemic has brought about significant differences in food purchase preferences. When the virus is spreading, consumers are generally less willing to shop in grocery stores but also change their preferences towards food; we see a general move towards healthier diets, an increase in the consumption of local products due to food safety concerns, and changes in the way food is obtained, such as the increase in online food shopping for food. While online shopping in Slovakia during the COVID-19 pandemic has risen in general, online purchases from domestic retailers saw the greatest increase, while the turnover of foreign retailers decreased over the same period (Križan et al. 2020). 


\section{Conclusion}

It is obvious that changes in consumption, lifestyle or culture are also the result of the qualitative impact of trade, and these factors thus also play a role in influencing consumer behaviour. All these changes have led to an increase in the availability of goods on the market, improvements in terms of price, quality and assortment, an increase in consumer culture despite the temporary reduction in the typical patterns of purchase and consumption which the impact of the COVID-19 pandemic has caused. Taking all of these transformations into account, we can say that Slovak consumers have left behind the traditional shopping habits of the past and are now largely guided by their feelings or impulses.

This article was recommended for publication in a scientific journal Young Science by: Ing. Elena Šírá, PhD.

This work was carried out as part of the research project titled"Relational marketing research - perception of e-commerce aspects and its impact on purchasing behaviour and consumer preferences" supported by VEGA under grant no. VEGA/1/0694/20 .

\section{References}

1. Awais, M. and Samin, T. 2012. „Advanced SWOT Analysis of E-commerce.” International Journal of Computer Science Issues (IJCSI), 9 (2): 569-574.

2. Baláž, V. 2006. „Slovakia: EU Accession and Cross-Border Travel.“ In Tourism in the New Europe: The Challenges and Opportunities of EU Enlargement. D. Hall, Melanie Smith, and Barbara Marciszewska (Eds). Wallingford: CABI, pp. 92-103.

3. Baláž, V. and Williams, A. M. 2005. „International tourism as bricolage: an analysis of Central Europe on the brink of European Union membership. “ International Journal of Tourism Research, 7 (2): 79-93.

4. Bilková, K., Barlík, P., Križan, F., Kita, P. and Zeman, M. 2017: „Cezhraničné nakupovanie slovenských spotrebitel'ov v Rakúsku." [Cross-border shopping of Slovak consumers in Austria]. In Maloobchod a špecifiká časovo-priestorového správania spotrebitel'ov. Križan, F. et al., (Eds), Bratislava: Univerzita Komenského.

5. Britchenko I. 2020. „Pandemic economic crisis: essence, reasons, comparative characteristics, opportunities.” Britchenko I., Bezpartochnyi M. (Eds.) In New trends in the economic systems management in the context of modern global challenges: collective monograph. VUZF University of Finance, Business and Entrepreneurship. - Sofia: VUZF Publishing House "St. Grigorii Bogoslov". pp. 8-19.

6. Бритченко И.Г. 2001. MARKETING MANAGEMENT ОРГАНИЗАЦИИ: потенциал и система / Брітченко И.Г., Бритченко Г.И. - Донецк: ДонНУ, 279 с. [Britchenko I.G. 2001. MARKETING MANAGEMENT ORGANIZATION: potential and system. Britchenko I.G., Britchenko G.I. (Eds).Donetsk: DonNU, pp. 279].

7. Búzik, B. and Zeman, M. 2020. „Hodnoty v regulácii spotrebitel’ského správania. [„, Values in the regulation of consumer behavior]. Sociologia 52 (5): 411-431.

8. Bystrická, K. 2013. Internetový obchod. [Online store]. Bratislava: Iura Edition.

9. Civáň, M. and Krogmann, A. 2012. „Nákupný turizmus medzi Slovenskom a Rakúskom.“[Shopping tourism between Slovakia and Austrin]. In A series of contributions from the International Scientific Conference for Doctoral students and young scientists of MERCURY. Bratislava: Ekonomická univerzita, pp.75-83.

10. European Ecommerce Report. 2019. „E-commerce in Europe 2019”. Accessed 2019. https://www.ecommerceeurope.eu/wpcontent/uploads/2019/07/European_Ecommerce_report_2019_freeFin al-version.pdf 
11. FMCG \& RETAIL. 2020. „Covid-19 mení nákupné správanie slovenských spotrebitel’ov.“ Accessed November 2020. https://www.nielsen.com/sk/sk/insights/article/2020/covid-19-meni-nakupne-spravanieslovenskych-spotrebitelov/

12. Gangeshwer, D. K. 2013. „E-commerce or Internet Marketing: A business Review from Indian context.“ International Journal of u-and e-Service, Science and Technology, 6 (6): 187-194.

13. Gburová, J. and Bačík, R. 2013. Marketingová komunikácia. [Marketing communication]. Prešov: Bookman, s.r.o.

14. Hasan, J. and Uhrin, V. 2020. „Teoretický model určenia vplyvu e-commerce v maloobchode a spotrebe“ In Kde nakupujeme, čo nakupujeme a prečo nakupujeme: lokality maloobchodu a spotreby a správanie spotrebitel'ov. [Theoretical model for determining the impact of e-commerce in retail and consumption "In Where we buy, what we buy and why we buy: retail and consumption locations and consumer behavior]. Križan, F. (ed.). Bratislava: Univerzita Komenského, pp. 136-166.

15. Hasan, J. 2019. „E-commerce and its Impact on Retail Stores in Slovakia.“ Studia Commercialia Bratislavensia, 12 (41):16-23.

16. Heureka 2020. „Slováci v roku 2019 na e-shopoch vytvorili nový rekord - minuli 1,36 miliardy eur.“ Accessed January 1. https://onas.heureka.cz/slovaci-v-roku-2019-na-e-shopoch-vytvorili novy-rekordminuli-136-miliardy-eur

17. Hoeijmans, N. 2020. Spanish e-commerce grows 55\% due to COVID-19. 2020. Accessed January 21. https://cross-border-magazine.com/spanish-e-commerce-grows-55-due-to-covid-19/.

18. Horváth, J., Bačík, J. 2020. „Analytický pohl’ad na nakupovanie tovarov a služieb zastupcami generácie Y.“ In Teoretické a praktické východiská vplyvu moderných technológií na spotrebitel'ské správanie $\mathrm{V}$ podmienkach elektronickej a mobilnej komercie. [An analytical view of the purchase of goods and services by representatives of the Y generation. "In Theoretical and practical background of the influence of modern technologies on consumer behavior in the conditions of electronic and mobile commerce]. Bačík, R., Gburová, J., Fedorko, R. (Eds). Prešov: Bookman s.r.o.

19. IAB Slovakia 2019. „Návštevnost’ slovenského internetu v roku 2019.“ [Slovak internet traffic in 2019]. Accessed https://www.iabslovakia.sk/wpcontent/uploads/2020/03/IAB_Sprava_IABmonitor_2019_FINAL.pdf>

20. Jucha, P. and Corejova, T. 2020. „Possibility of Order Delivery from e-Shop Within Last Mile.“ Practical Example from Slovakia. Management, 20: 22.

21. Križan, F., Zeman, M., Bilková, K., Kita, P. and Barlík, P. 2017. „Cezhraničné nákupné správanie spotrebitel'ov zo Slovenska." [Cross-border shopping behavior of consumers from Slovakia]. Hainburg an der Donau Austria. Geographia Cassoviensis, 11 (2): 124-136.

22. Križan, F., Barlík, P. and Bilková, K. 2016. „Nákupné správanie mladých spotrebitel’ov: Ako často nakupujú (prípadová štúdia z Bratislavy).“ [Shopping behavior of young consumers: How often shop (case study from Bratislava)]. Geografia 24: 40 - 43.

23. Križan, F. and Lauko, V. 2014. Geografia maloobchodu. [Retail geography]. Bratislava: Univerzita Komenského, pp. 196

24. Štefko, R. et al. 2012. Úvod do marketingu služieb. [Introduction to service marketing ]. Prešov: Bookman, S.r.o

25. Jarossová, M. A. 2015. „Nákupné správanie spotrebitel’ov a ich postoje k biopotraviním, tradičným a funkčným potravinám." [Consumer shopping behavior and their attitudes towards organic food, traditional and functional foods]. Stuadia commercialia Brafislavensia, 8 (31): 372-383.

26. Kahle, L. R. and Close, A. G. 2011. Consumer behavior knowledge for effective sports and event marketing. London: Routledge.

27. Kakalejčík, J. B. M. F. L. 2015. „Analýza faktorov ovplyvňujúcich nakupovanie prostredníctvom internetu.“ [Analysis of factors influencing online shopping]. Journal of Management and Economics. Bratislava: MANEKO.

28. Kotler, P. and Keller, L. K. 2007. Marketing management. 12th Edition. Praha: Grada Publishing, a.s.

29. Khan, M. S., Mahapatra, S. S. 2009. „Service quality evaluation in internet banking: An empirical study in India.“ International Journal of Indian Culture and Business Management, 2: 30-46.

30. Kita, J. et al. 2005. Marketing. 5. edition. Bratislava: Jura edition.

31. Kovács, A. 2013. „On borders, border regions and cross-border retail-trading.“ Scientific papers of the University of Pardubice. Series D, Faculty of Economics and Administration. 28 (3/2013).

32. Križan, F., Bilková, K., Hencelová, P., Danielová, K., Čuláková, K. and Zeman, M. 2020. Nákupné správanie spotrebitel'ov na Slovensku: vybrané kapitoly. [Consumer purchasing behaviour in Slovakia: selected chapters.] UK Bratislava.

33. Križan, F., Bilková, K., Kita, P., Kunc, J. and Barlík, P. 2015. „Nákupné centrá v Bratislave a atribúty ovplyvňujúce preferencie spotrebitel'ov." [Shopping centers in Bratislava and attributes influencing consumer preferences.]. Geografický časopis, 67 (4): 341-357. 
34. Kunc, J., Tonev, P., Szcyrba, Z. and Frantál, B. 2012. „Shoping centres and selected aspect of shopping behaviour (Brno, the Czech republic).“ Geographia technica, 16 (2).

35. Kunešová H. and Eger L. 2017. ,Evaluation and comparison of B2C e-commerce intensity in EU member states.“ E\&M $\quad$ Ekonomie a Management, $20 \quad$ (4). Accessed 2017. https://www.semanticscholar.org/paper/EVALUATION-AND-COMPARISON-OF-B-2-C-ECOMMERCEIN-EU-Kunešová-Eger/216029480758a6096a2c807e113bcf404db01d27

36. Laudon, K. C. and Traver, C. 2016. E-Commerce 2014: Business, Technology and Society. 11th edition. London: Pearson.

37. Listrak. 2020. „eCommerce in the wake of COVID-19.“ Accessed March. https://www.listrak.com/covid19

38. McKinsey. 2020. „Consumer sentiment and behavior continue to reflect the uncertainty of the COVID-19 crisis.“ Accessed October 26. https://www.mckinsey.com/business-functions/marketing-and-sales/ourinsights/a-global-view-of-how-consumer-behavior-is-changing-amid-covid-19

39. Minculete, G. 2013. „Issues regarding electronic commerce and e-marketing.“ In International Scientific Conference" Strategies XXI", Carol I" National Defence University, (2): 26.

40. Mitríková, J. 2017. Geografia maloobchodu (vybrané kapitoly). [Geography of retail (selected chapters)]. Prešov: Bookman.

41. Mitríková, J., Šenková, A. and Antolíková, S. 2015. „Application of the huff model of shopping probability in the selected stores in Prešov (Prešov, the Slovak Republic).“ Geographica Pannonica, 19 (3): 110-121.

42. Nastišin L'. 2020. „Analysis of upcoming trends in marketing social media.“ In: Teoretické a praktické východiská vplyvu moderných technológií na spotrebitel'ské správanie v podmienkach elektronickej a mobilnej komercie: nekonferenčný vedecký zborník recenzovaných štúdií. Bačík, R., Gburová, J., Fedorko, R. (Eds.). Prešov: Bookman s.r.o., pp. 6-13.

43. Ohidujjaman, N. et al. 2013. „E-commerce Challenges, Solutions and Effectiveness Perspective Bangladesh.“ In International Journal of Computer Applications, 70 (9): 9-17.

44. Oleárová, M. 2020. „Prehl'ad aktuálního stavu e-commerce vo svete počas pandémie COVID-19.“ In Teoretické a praktické východiská vplyvu moderných technológií na spotrebitel'ské správanie v podmienkach elektronickej a mobilnej komercie Nekonferenčný vedecký zborník recenzovaných štúdií. Bačík, R., Gburová, J., Fedorko, R. (Eds). [An overview of the current state of e-commerce in the world during the COVID-19 pandemic. In: Bačík, R., Gburová, J., Fedorko, R. 2020. Theoretical and practical basis of the influence of modern technologies on consumer behavior in the conditions of electronic and mobile commerce Non-conference scientific proceedings of peer-reviewed studies]. Bookman s.r.o., pre Fakultu manažmentu Prešovskej univerzity v Prešove, 2020.

45. Qin, Z. 2010. Introduction to E-commerce. Beijing: Tsingua University Press

46. Scott, D.M. 2010. The New Rules of Marketing and PR: How to Use Social Media, Blogs, News Releases, Online Video, and Viral Marketing to Reach Buyers Directly. New Jersey: John Willey \& Sons.

47. Shih, C. 2010. Vydělávajte na Facebooku. Brno: Computer Press.

48. Sikandar, M. 2020. „Mapping The Impact Of COVID-19 Pandemic On E-Commerce.“ Accessed 2020. https:/cedcommerce.com/blog/impact-of-covid-19-on-ecommerce/

49. Sikos, T. T. and Kovács, A. 2008. „Új trendek a határ menti kiskereskedelemben Délnyugat-Szlovákiában.“ Területi Statisztika, 11(6): 724-733.

50. Spilková, J. 2012. Geografie maloobchodu a spotřeby. [Geography of retail and consumption]. Věda o nakupování. Praha: PřF UK.

51. Sullivan, P. M. and Kang, J. 1997. „Information sources and motivational attributes of Canadian crossborder shoppers: a pilot study.“ International journal of commerce and management, 7 (1): 88-107.

52. Štrach, P. 2020. „How covid-19 is changing consumer behavior: Identifing new segments and segmentation criteria.“ In. Marketing Science and Inspirations. Scientific journal is aimed at the area of marketing and marketing management, 15 (4).

53. Taylor, M. 2020. "Trade coffee launches a five-pound bag to satisfy consumer demand and to keep their roasting partners in business during the pandemic.” Accessed April 7, 2020, www.forbes.com.

54. Tomek, G., V. Vávrová. 2011. Marketing od myšlenky k realizaci. [Marketing from idea to implementation]. Praha: Professional Publishing.

55. Tömöri, M. 2010: „Investigating shopping tourism along the borders of Hungary: A theoretical perspective.“ GeoJournal of Tourism and Geosites, 6 (2): 202-210.

56. Trembošová, M. 2009a. „Vývojové etapy maloobchodnej siete mesta Nitra v rokoch 19922008. “[Development phases of the retail network of the city of Nitra in 1992-2008]. In. Geografické aspekt stredoevropského prostoru. Hübelová, D., (Eds.). Brno: Masarykova Univerzita, pp. 161-165.

57. Trembošová, M., Dubcová, A. and Civáň, M. 2016. Geografické aspekty maloobchodnej siete mesta Trnava a nákupné správanie jej obyvatel'stva. [Geographical aspects of trnava's retail network and the purchasing behaviour of its population]. Nitra: Univerzita Konštantína Filozofa v Nitre). Miroslava Trembošová, (Eds.), pp. 175. 
58. Ullman, L. 2013. Effortless E-Commerce with PHP and MySQL: Effort EComme PHP MySQL _p2. Berkeley: New Riders.

59. Valassis. 2020. „Changes In Consumer Behavior Amid COVID-19.“ Accessed 2020. Changes In Consumer Behavior Amid COVID-19 - Valassis

60. Vysekalová et al. 2012. Psychologie reklamy. 4., rozšířené a aktualizované vydání. Praha: Grada.

61. Williams, A. M., Baláž, V., Bodnárová, B. 2001. „Border regions and trans-border mobility: Slovakia in economic transition.“ Regional Studies, 35 (9): 831-846.

62. Williams, A.M. and Baláž, V. 2002. „Česká a Slovenská republika: koncepčné problémy ekonomickej analýzy cestovného ruchu v procese transformácie." [Czech and Slovak Republic: conceptual problems of economic analysis of tourism in the process of transformation]. Management cestovného ruchu , 23 (1): $37-$ 45

63. Williams, A.R.T. et al. 2006. „Self-Assessment against Business Excellence Models: A Critique and Perspective.“ Total Quality Management and Business Excellence, 17(10): 1287-1300.

64. Anonym, 2009. Dohovor o ochrane svetového kultúrneho a prírodného dedičstva [online]. [cit. 2013-0715]. Dostupné z: http://www.enviroportal.sk/dohovory/dohovory-detail.php?dokument=154 